\title{
Digital writing tools from the student perspective
} Access, affordances, and agency

\author{
Helene Dahlström ${ }^{1}$
}

Received: 21 June 2018 / Accepted: 27 November 2018 / Published online: 4 December 2018

(C) The Author(s) 2018

\begin{abstract}
Along with digital development, new possibilities for communicating have emerged. The younger generation has adopted these new possibilities to a great extent. In order to be able to utilise the opportunities offered by digital tools when writing, access to digital tools is essential. Schools need to develop a writing education that meets students' contemporary writing needs. In considering this, it is important to learn more about the gains and the losses in digital writing. The purpose of this study was to understand and discuss the relation between students' digital access, students' perceived affordances with digital writing, and student agency. The methods used were a statistical survey and qualitative interviews. Six classes from five different schools located in a municipality in the middle of Sweden were chosen as an informant group. The results indicate that the most common condition concerning students' digital access was that students shared digital tools for writing with their families. An analysis of affordances was carried out to interpret the empirical findings from the qualitative data. Affordances that emerged were: write-ability, edit-ability, story-telling ability and accessibility. In addition, the ways in which digital access and the affordances perceived can be related to student agency were analysed. The main conclusion was that given the conditions of digital access and opportunities to practice, the affordances of digital writing can increase student agency. In turn, this suggests that writing education that focuses on student agency can contribute to equity in writing activities.
\end{abstract}

Keywords Affordances · Agency · Digital tools · Students' views

\section{Introduction}

Communication and the ways we make meaning are changing. Along with digital development, meaning making and communication have also changed. In

Helene Dahlström

helene.dahlstrom@miun.se

1 Department of Education, Mid-Sweden University, 85170 Sundsvall, Sweden 
contemporary communication, resources such as writing, images and music are all commonly used for meaning making (Kress 2010). Furthermore, the way we write is changing. Digitalisation has brought increased opportunities to choose among digital writing resources. Finally, the change includes a shift from an unquestioned authority that provides guidance for semiotic action in education, to communication and knowledge produced by anyone, at any time. Due to these changes, it becomes relevant to discuss how meaning is made in education, and to ask questions about the possibilities and the challenges in the use of digital tools in education (Barton 2007; Kress 2010).

As digital development is a considerable part of the change in communication, it becomes relevant to discuss whether all students have equal opportunities to take advantage of the possibilities offered. One requirement for being able to perceive the new possibilities offered, is to have access to digital tools. In Sweden, due to socioeconomic background, access to digital tools differs among primary school students (Statens medieråd 2017). Therefore, schools play an important role in bridging the inequality that has appeared between students (Samuelsson 2014; van Deursen and van Dijk 2014). Apart from access to digital writing tools, education that enables the potential of these tools to be discovered and utilised by the students is also required. According to Björkvall and Jacquet (2014), one starting point can be to draw attention to the affordances offered by digital writing tools. The concept of affordance is used in this article, to analyse how 10-12 year old students perceive the affordances offered when using digital writing tools. The concept of affordances is seen as relational, meaning that the affordances offered shape the conditions for what it is possible to do (Hutchby 2001). The concept of agency refers to students' active participation and their ability to act independently in writing activities in a school context (Bezemer and Kress 2016; Selander and Kress 2010). Agency is also understood as something that is achieved in and through engagement with a particular situation, for example students' narrative writing in a classroom context (Biesta and Tedder 2006; Emirbayer and Mische 1998).

The current debate about what digital writing may provide in terms of possibilities and constraints has resulted in research on how students' writing is affected by the use of digital writing tools (Agélii Genlott and Grönlund 2016; Dahlström and Boström 2017; Mangen and Balsvik 2016). There is also research on students digital access in relation to equality (Samuelsson 2014; van Deursen and van Dijk 2014). However, there seems to be a research gap concerning the relation between the two fields of digital access and digital writing. In Sweden a national strategy for the digitalisation of education was created (Swedish Ministry of Education 2017a). In this strategy three areas were in particular focus: Digital competence for everyone in the school system, Equal access and use, and Research and evaluation of the possibilities of digitalisation. Based on this strategy, changes were made in the Swedish curricula for compulsory school concerning education and students digital competences (Swedish Ministry of Education 2017b). In relation to digital writing these changes in the curricula are aimed at education providing students with the capacity to write and edit text, both digitally and by hand. These changes can be understood as the Swedish school system intending to bridge digital diversity, and to offer students opportunities for writing education that includes learning digital writing, as well as handwriting. Therefore, learning about the possibilities that digital writing provides can be valuable when developing this sort of education. One way of learning about the possibilities of the new ways of writing is to ask the younger generation who are in education (Erixon 2016). 
The focus of the study presented in this article emerged out of the challenge of giving all students the chance to utilise the possibilities of digital writing in education. Thus, the aim of this article is to discuss and understand the relation between students' digital access, students' perceived affordances of digital writing and student agency.

Such knowledge can lead to a deeper understanding of how writing education can be designed in order to give students more equal conditions to express meaning while writing in general, and when writing stories in particular. The analysis has been guided by the following research questions: What access to digital tools do students have? What affordances do digital tools for writing offer students when writing stories? How can the relation between digital access and the affordances perceived in digital writing be understood in relation to student agency?

\section{Previous research}

This section is organised in three different parts. Initially, research on digital access is presented, followed by research on possibilities and affordances offered by digital writing tools. The section is concluded by describing research on agency and digital tools.

\subsection{Digital access}

Technical equity is about having access to digital technology as well as the opportunity to learn the skills needed to use technology in a way that meets an individual intention (Samuelsson 2014). Increasing access to digital tools in school is sometimes put forward as part of the compensatory assignment, in order to give all students equal opportunities for using digital tools. However, simply increasing access, as in so-called one-to-one initiatives, often results in continuing digital inequality in terms of use, and of being able to take advantage of the possibilities offered by the digital tools (Park and Jae Kim 2014; Samuelsson 2014). An individual's background influences how digital technology is used. A new digital divide is emerging between students who have digital competence, and those who do not (van Deursen and van Dijk 2014). In order for students to be able to benefit from both current and future education, that part of the school's mission which is to provide every student with digital skills is important here (Samuelsson 2014). According to Samuelsson (2014), the existence of digital inequality among students can be explained by the fact that digital tools at home are often shared with other family members. Samuelsson also found that the students who had high levels of access to digital tools at home were the students who had greater digital skills.

\subsection{Possibilities offered}

The possibilities of using software scaffolding programs seem to be of decisive importance, according to previous research. When using programs such as speech synthesis and spelling check, students write longer texts and struggling writers are included in writing activities to a greater extent (Agélii Genlott and Grönlund 2016; Hultin and Westman 2014; Liberg 2014). One group of students who can benefit from using digital software programs such as word processors and speech synthesis is students with Swedish as their second language, according to Dahlström and Boström (2017). These researchers compared student narrative texts, written 
under three different writing conditions: using pen and paper, using digital writing tools, and using digital writing tools with speech synthesis. Results indicated that students with Swedish as their second language wrote longer texts, as well as producing more accurate language when using digital tools, in comparison with their handwritten texts. Another Swedish study, a social semiotic ethnography, showed that when students could use the digital tool resources, there was a difference in how different students benefited from them. Some students used the digital resources only as a machine for schoolwork, while others used the resources in several different contexts. For example, one student wrote blogs at home with many different readers, and at school she wrote school tasks aimed at the teacher (Björkvall and Jacquet 2014).

The possibilities reported by students in interview studies concern, to a great extent, how the use of word processor as a scaffolding tool can affect students' writing (Clarke and Svanaes 2012; Ghandoura 2012; Olofsson et al. 2017). In a study where 100 Swedish students in the lower secondary school were asked about their attitudes towards new technology in their Swedish lessons, Erixon (2016) found that most students were positive about digital writing. Students' positive attitudes towards writing with the new technology have to do with speed and efficiency, according to Erixon (2016). The chance to improve writing, taking notes and keeping a structure are common findings from studies regarding upper secondary school students' perspectives on the possibilities and the challenges of using digital tools in education. Arguments mentioned it being faster and easier to write digitally. Challenges reported from these studies were technological problems, and a gap in digital competence between teachers and students (Håkansson Lindqvist 2013, 2015; Olofsson et al. 2017).

The affordances of digital reading and writing were investigated as well as paper and pen affordances, in an Italian context, (Fortunati and Vincent 2014). The overall results showed that writing on paper had more positive affordances as compared to digital writing. The digital affordances perceived were the ability to use the automatic correction function, and being able to edit the text. Some students also mentioned that digital writing was less exhausting for their hands. The perceived affordances of reading and writing on paper and digital writing were also studied by Taipale (2014). Taipale (2014) replicated Fortunati and Vincent's (2014) study in the Finnish context. In contrast to the Italian context, college students in Finland valued writing on a keyboard the most, especially because it enabled editing the text quickly, which increased their textual productivity. Some affordances of digital writing were taken for granted and the students did not recognise their non-digital alternatives according to Taipale (2014). Other affordances that the students described were the possibilities of documenting ideas quickly, it being easier to remember what their thoughts were, edit-ability and the ability to hide their own poor handwriting. These differences may imply that Finish students are more embedded in the digital world than Italian students (Taipale 2014). Writing with digital tools appears to provide new opportunities for creating texts. The digital writing process can include a great deal of editing while writing. This new process of writing means that students move back and forth in the text, and do not, as before, follow a linear writing process (Kress 2003; Stapleton 2012; Åkerfeldt 2014).

\subsection{Agency and digital tools}

Few studies were found that focused on both the affordances of writing tools, and on student agency. One study, focusing on student agency and literacy education through 
digital technologies involving a class of Australian 10-12 year old students, was found to be relevant. This study showed a change in agency. The students were given increased options of participating in activities that enabled them to exercise control over the learning context. While composing persuasive texts, students were observed working and reaching literacy goals when they took digital initiatives. There was no scaffolding provided on how to use the technology, and the emphasis was on the literacy content, according to Simpson and Walsh (2014). Although the purpose was not to focus on the use of technology, the teacher became frustrated when the lack of digital competence took time from the literacy education. Findings from a Singaporean study describe how writing instruction in English classrooms is still teacher directed. The perspective of students as independent writers, and of student agency, remains underdeveloped. According to Kiss and Mizusawa (2018), writing classrooms should be designed to scaffold students to discover what they can do, rather than what teachers believe the students can do. According to Klerfelt (2007), the possibilities for student agency are affected by whether or not the teacher sees digital resources as mediational means, and gives the students access to resources as active participants.

\section{Theoretical framework}

\subsection{Materiality and semiotic resources}

Written language can be produced materially in different ways. There are basic differences in the materiality of writing, meaning that the basic features of writing are related to the materiality of the technology that is used to mediate the writing (Merchant 2007). When using a pen and a paper to represent meaning there is direct contact with the hand that forms the letters on the paper. The patterns made on the paper are created from the memory of the form of the alphabetic writing system. When using a keyboard or a touch screen, choices are made from a palette of ready made letters and symbols, and the writing appears on a screen instead of on paper (Merchant 2007). The use of semiotics with a specific materiality produces semiotic affordances (possibilities of action) or meaning potential, possibilities and limitations of different semiotic resources in a particular context (van Leeuwen 2005). Semiotic resources can be defined as:

the actions and artefacts we use to communicate, whether they are produced with our vocal apparatus; with the muscles we use to create facial expressions and gestures, etc.- or by means of technologies - with pen, ink and paper; with computer hardware and software; with fabrics, scissors and sewing machines, etc. (van Leeuwen 2005, p. 3).

\subsection{Affordance}

Closely related to the term semiotic potential is the term affordance (Gibson 1986), meaning that affordances are the potential uses of a given object. According to Gibson (1986), humans, just like animals, approach objects in their world in terms of affordances, i.e. the possibilities for action that are offered to them, and not in terms 
of their qualities. Gibson also states that an affordance does not change because an individual's needs change, the affordance is what it is, with the possibility of being perceived. According to Hutchby (2001), another way of defining affordances is to see them as being relational.

This view emphasises the relational aspects of the affordances, meaning that affordances cannot be seen as human properties, nor as the properties of artefacts. Rather, affordances can be seen as the space between the human and the artefact, where opportunities for action are offered.

Hutchby also stresses that humans have to learn about some affordances offered. For example, some affordances are designed into the artefacts, such as different software programs that are designed as digital tools, as Norman (1990) stated earlier. There are different ways of responding to the affordances of action and interaction that an artefact offers. It is possible to study this variation of responses empirically, if we accept the possibilities for agentic actions in the relation between human intentions and the affordances of the artefacts. (Hutchby 2001). All the resources that we use to communicate have affordances. Danielsson and Selander (2016) describe the term affordance as the meaning potential offered, or as the possibilities and the limitations of various semiotic resources in a certain context, for example a school context. From a didactic perspective, the opportunity to choose between different semiotic resources could be advantageous for student agency. In this article the concept of affordance is used to analyse the possibilities for action that primary students perceive when using digital writing tools, when creating stories. In this article, the concept of agency is used in order to analyse how the affordances perceived by the students can be understood in relation to student agency. Below, this concept is described further.

\subsection{Agency}

Meaning making and the production of texts are central concepts in social semiotics where the word making implies a maker, and therefore, the concept of agency becomes central (Kress 2010). In educational settings there has been a shift in agency, from the fact that teachers previously created agency for the students, towards the learner's (student's) agency being in focus (Bezemer and Kress 2016). Different tools for writing offer different choices and digitalisation has increased the possible choices for meaning making. These choices are made by the individual in a social context, e.g. in the classroom (Kress 2010). The tools can be seen as a means of mediating the purposes that the student has (Björkvall and Karlsson 2011). Student agency means that students are allowed to acquire an action space. When students are given scope for action, and the teachers have a permissive attitude, then student agency can take place (Baynham 2006).

Agency can be understood as something that is achieved in, and through, engagement with a particular temporal relational situation, for example engagement in the writing of stories in a classroom situation (Biesta and Tedder 2006; Emirbayer and Mische 1998). The idea of achieving agency moves the explanation away from the individual, where agency can be seen as an individual possession. Agency is not something people can have. This view allows for the empirical possibility that the achievement of agency is related to the availability of resources (Biesta and Tedder 2006). The availability of resources is closely related to agency and design in a social semiotic theory, where the individuals' meaning making design, relates to choices (Selander and Kress 2010). The concept of design is described further in the next section. 


\subsection{Design}

The concept of design for understanding communication can be said to reflect the linguistic change brought about by a shift in the power relationships in society, as well as in school. Due to changes in communication, schools which were previously expected to be the sole supplier of knowledge, now have an altered task. Knowledge is now being created everywhere by everyone. Young people perceive themselves as producers of the knowledge they need, and as authors of texts that meet individual and social needs. This new way to produce knowledge tends to collide with the sometimes more traditional and authoritarian student and knowledge perspectives found in education (Kress 2010). Therefore, this shift of power is of importance to how teachers design their teaching. The concept of design can be helpful in understanding these new complex learning situations (Leijon and Lindstrand 2012).

Design, as a concept, has replaced competence, in a social semiotic approach when discussing knowledge, communication and meaning making. Design is seen as an essential principle in the process of meaning making. According to Kress (2017), the process of meaning making is made in a sequence of interactions involving at least two actors. One individual's action is initiating and the other individual's action is responsive, but they both make meaning out of their interest. For example, the initiating actor, can be the teacher. Making choices and with the resources available, he or she designs the teaching based on an educational interest. The second actor, the student here, creates his or her own learning from the resources given them by the teacher. How different students respond to what is offered depends on interest and previous experiences concerning the resources offered to them. Here, design is semiotic work and it produces meaning (Kress 2010).

In this study, design has three meanings. First, design involves how the media available have been constructed for communication. Second, the concept of design in a didactic perspective can be seen as a way to form the conditions for learning (Selander and Kress 2010). Third, for the learner, design involves how a learner is given opportunities to make his or her own choices, based on the semiotic resources available and according to the purpose and aim of the representation (Kress 2010; Rostvall and Selander 2008). Therefore, being familiar with the affordances provided by different modes and media is crucial to making choices (Kress 2010).

\section{Methods}

The study aims to develop knowledge about affordances offered by digital writing tools and student agency. Since one prerequisite for perceiving affordances with digital writing tools is to have digital access, it also became relevant to describe how student access to digital tools was related to student agency. In order to encompass this aim, a research design that included both qualitative and quantitative methods was used. The design can be described as mainly qualitative, but in order to describe digital access applicable to a wider range of students, a survey was included in the study.

\subsection{Participants}

The participants included in the study were 111 Swedish middle school students, 1012 years of age. Six classes from five different schools located in a municipality in the 
middle of Sweden were chosen as an informant group for this study. One of the schools was located in a multicultural suburban area, while the other four schools were located in smaller rural areas. The data collection started with qualitative interviews, the 12 participants were strategically sampled, in the sense of being chosen with the aim of fulfilling the criteria set in advance, in order to provide the study with relevant data with which to answer the research questions. The criteria were:

- A focus on the middle years with the motivation that this age group can be seen as already knowing how to write, because the focus was not on how to learn to write.

- The participants should have experience from writing with digital tools as well as with pen and paper. Therefore, classes where students were only allowed to use either digital tools or pen and paper were not an option.

The selection of classes for the survey can be regarded as a cluster sampling (Grey 2013). Clusters, in this study, mean that students are naturally placed in classes, and all the students in the classes participated. The criteria were the same as for the smaller sample, i.e. the interviews. In these classes there were 99 students, aged 10-12. The data was generated in six different schools in the central region of Sweden, during 20162017.

\subsection{Procedure}

The data were collected and analysed both separately and as a whole. Initially, in the first phase the interview strand was conducted and completed. Phase two, the survey, with the aim of gathering information about students' access to digital tools, also gave the opportunity to collect a broader view on some of the questions in the interviews. As the number of students included was limited, the results apply to this particular group of students alone, and it is therefore difficult to make any generalised claims.

\subsubsection{Qualitative interviews}

Qualitative interviews were completed with 12 students, aged 10-11 years old. There were six boys and six girls with various access to, and competence in digital tools for writing. As the aim was to understand the students' views concerning the affordances of digital writing tools, semi-structured interviews seemed to be the best method for the purpose, as interviews are seen as a powerful tool to collect qualitative data (Kvale 2007). An interview guide was constructed with open questions, which also made it possible to ask supplementary questions if needed. The questions were about students' views on the possibilities and constraints of using digital tools. Some questions concerned students' access to digital tools. The interviews lasted for 15-30 min. All interviews except one were recorded. One student did not want to be recorded, so in this case, notes were taken. All the interviews were transcribed. This strand of inquiry was supplemented by 67 open-ended answers from the survey. Of the 99 questionnaires, 67 students had written answers to the open-ended questions.

To analyse the data, an affordance lens was used in order to be able to acquire students' perceptions about the affordances when using digital writing tools, when creating stories. The analysis is influenced by an relational perspective on affordances (Hutchby 2001). The 
focus was on the possibilities that emerged in the meeting between students and the material tools, in the action of writing stories. The first step in analysing the data, was to get a brief understanding of students' expressions, using an affordance lens. This was done by an initial general listening to the students meanings as expressed in the interviews, and by reading their open-ended answers. The next step was to transcribe all the data. In this manner an understanding of the data emerged and through an affordance lens, it was possible to identify affordances and some of their key characteristics. The affordances identified were based on the action possibilities described by the students, and the corresponding characteristics of each affordance. Thereafter the concept of agency was used for further interpretation and analysis, in order to understand what the different affordances could mean in relation to student agency.

\subsubsection{The survey}

A total of 99 students in four different schools were given the opportunity to answer the survey. All the students answered. One reason for the $100 \%$ response rate was that I personally visited most of the classes and participated during the lesson when the students filled in the questionnaire. In two of the classes, the class teacher taught the lesson when the students answered the questions herself.

The survey was operationalised from the study's research questions, and consisted of 15 questions. The survey started with some background questions, followed by Likertscale questions about digital access at home as well as in school. Some questions addressed the frequency of using different tools. The questionnaire also contained a number of questions concerning students' views about using different tools for writing stories. Some of these questions were open-ended questions.

The students answered the survey questionnaire on paper. The questionnaire measured students' access to digital tools at home, as well as in school. The response alternatives to these particular questions were. if they had access to devices of their own or if they had shared access within the family. First the data were coded, by numbering the different answers. The coded data were then analysed using cross tabulation. Students were also asked about which tools they used most frequently for writing. Frequency distribution was used to answer the question. The different descriptive analyses were carried out in the software program SPSS. The analysis of the open-ended questions concerning digital access was conducted using content analysis (Miles et al. 2014). Based on the research questions, students' expressions from interviews and together with the open ended questions, were sorted into content areas. The next step was to divide the areas into suitable meaning units, followed by condensation of meaning units. Finally, the condensed meaning units were allocated a code. The codes were then sorted into different categories. Together, the categories reflect the main message of the interviews (Graneheim and Lundman 2004). Finally, six categories could be formulated into three themes. The concept of agency was used for further interpretation and analysis, in order to understand what digital access could mean in relation to student agency.

\subsection{Trustworthiness, credibility and ethical issues}

One way to establish trustworthiness in a study is to ensure credibility. According to Merriam (1998) creditability addresses the question of how congruent the findings are 
with reality. One strategy used in this study in order to see how the findings are congruent, is to account for personal biases that may influence the findings. The researcher is the major instrument of data collection and analysis (Creswell 2014). As a former teacher and special needs educator I entered the study with an preunderstanding about the phenomenon under investigation, namely students' digital writing. This preunderstanding can be seen as adding something but also aggravating how congruent the findings are with reality. In the sense of having an understanding about both the context and the phenomenon under study, it is an addition. However, the fact that I had this understanding can be seen as aggravating, due to the potential of foreseeing some of the findings. In order to add more credibility to the findings in this study two different kinds of debriefing sessions have been carried out. Firstly a seminar with other researchers was conducted, in order to discuss the interpretations of the data. Secondly to increase their credibility further, the findings have been discussed with teachers who have experience of writing in education, in order ensure that the findings are consistent with their own teaching experience. According to Miles et al. (2014) asking people who have similar experiences to the participants involved in the study, is one way of seeing if the findings are congruent with reality. Finally, the examination of previous research findings is done to further ensure trustworthiness, when comparing the findings' congruence with past studies.

The participants were informed about the purpose of the study in advance. Since the students were not old enough to give their written informed consent to their voluntary participation in the study themselves, their caretakers had to give their written permission. The research followed the ethical codex of the Swedish Research Council (Vetenskapsrådet 2017), and the empirical data has been processed accordingly.

\section{Results}

In this section, a description of the students' access to digital tools is provided. The findings from the open-ended questions in the questionnaire, together with the findings from the interviews are then presented, according to the categorisation of affordances. Finally, these empirical findings are further interpreted and analysed in relation to student agency. This will be discussed further in the discussion section.

\subsection{Access to digital tools for writing}

Firstly, access to digital tools for writing was investigated, covering students' access in their homes, and at school. All the students had access to smartphones, but as the study was about tools for writing stories, smartphones were excluded from the study. The students responded in the questionnaire, answering whether or not they had personal access to the different tools at home, if they shared them with the family, or if they did not have any access at all.

Table 1 shows that the students had a high level of access to digital tools for writing at home. Students had the greatest access to computers, but the majority of the students had to share the computers with their family. Regarding having a device of their own, the tablet was the most common tool with 59 students having their own tablet. As described in Table 1, there was a small number of students who did not have access to a computer or a tablet at all. 
Table 1 Description of students' access to digital tools for writing at home, expressed in number of students

\begin{tabular}{llcc}
\hline & Own & Share & No access \\
\hline Computer & 35 & 55 & 9 \\
Tablet & 59 & 28 & 12 \\
\hline
\end{tabular}

The results from the content analysis show a similar pattern, a majority of the students described having access to digital tools for writing at home. Some students had a high level of access. One student noted:

I have my own computer, phone, I have two iPads and I have some headphones I think, and a TV of my own.

That sharing digital tools for writing in the family sometimes meant that they felt that they had a low level of access, was expressed by one student:

I love writing stories on the computer but do not use it very much because my dad has the computer, like, all the time.

All of the students reported that the school had computers to use for writing.

Tablets to use for writing were reported by 72 students. But according to the students, they were not allowed to use them to the extent they wanted to:

We have tablets at school, but my class has never used them.

When analysing the students' access to digital tools for writing, it becomes apparent that students who had the opportunity to use and practice with digital tools, could design their texts more freely. Practice was frequently mentioned as something important by the students, in order to be able to use the digital tools in the way they wanted. Although students perceived some of the affordances offered, they explained that they had to practise in order to be able to take advantage of them.

\subsection{The importance of having the possibility to practise with digital tools for writing}

The opportunity for digital practice, or the lack of digital practice appears to play a crucial role in how the students express themselves concerning writing with different tools. Results from the content analysis showed that some students wrote on computers or tablets all the time at home. As one student states:

I'm used to working with the computer and iPad at home. I write a lot on the computer at home. So I am pretty good on the computer. The computer is my best tool.

On the other hand, other students described a lack of opportunity to practise, due to the low level of access at home. They did not have computers or tablets, or they shared them with the family. Due to their lack of experience of computer use at home, it was difficult to write on computers at school. One student explains this relationship: 
I always write with a pen, we don't have a computer at home so when I write on the computer at school, it can feel quite strange. It is hard to find the letters on a tablet or a computer.

After they had written on tablets at school, some students with little experience of writing digitally described how it would have been good if they had initially learnt to master the tablet. One student expressed it like this:

If you started by learning to find the letters, then it would be faster for everyone to write stories. Then you could write three chapters during one lesson instead of one. The more you practise on the iPad, the longer the text will be.

Some students expressed wanting to write with digital tools more. The most common tools for writing in schools included in this study were shown to be pen and paper. A total of $58 \%$ of the students claimed that the most common tool used while writing stories in school was the pen, compared to $42 \%$ of the students who used digital tools most frequently.

In summary, these results provide insights into the access this particular group of students has to digital tools for writing. Even though students perceive some affordances, they still experience the need to practise in order to be able to take full advantage of the possibilities offered by digital writing tools.

\subsection{Affordances}

This section will present the findings of the affordance analysis. According to the students, the use of digital writing tools provided the most possibilities for writing stories. The constraints were fewer, and students described more obstacles when they had to write by hand. In this section, the four affordances identified are presented. Following this, the constraints perceived when using digital tools for writing stories are addressed.

\subsubsection{Write-ability}

There are different descriptions about the possibilities of writing a readable text, as afforded by digital writing tools. Often this meant that the students could write without spelling errors, and could use correct punctuation. As one student formulated this:

With a pen, I do not know ifI'm writing correctly. I have a little trouble spelling so writing on a computer is better because then I see when I spell wrongly, and I can write more.

For some students, this included the possibility of writing faster. To write faster could also be related to the possibility of writing a readable text in so far as it enabled teachers to read the text, as well as they themselves. This relation is expressed by a student:

It's faster to just press a key instead of shaping letters, you do not have to erase. It is possible to write a lot and quickly and yet it is possible to read it. If you write by hand, you must write slowly so that it is possible to read it. 
The possibility of using difficult words was perceived by some of the students. When the students used scaffolding tools such as the word processor or speech synthesis, the possibility of using words that they could not spell correctly could be seen as an affordance. A number of students also noted that they perceived the possibility of hearing if something in their writing was wrong.

\subsubsection{Edit-ability}

Students expressed that the affordance of edit-ability allowed them to edit the text, and that it became easier to erase and re-write. The students found it was a relief not to have to think about erasing by hand, and rewriting with a pen. One student said:

It is easier to erase. If you make a mistake, it will turn red and you don't have to use a rubber. You can just press a button to clear it without making it messy. It looks bad when you have to use a rubber and everything on the paper turns grey.

Some students explained that the edit-ability offered the possibility of writing without fear of making mistakes. If they made mistakes using digital tools, it was easy to correct. It was also easy to rearrange text if they got new ideas while they were writing, according to some students.

\subsubsection{Story-telling-ability}

When they could listen and hear what they had written, students perceived the possibility of being inspired to continue their story. Listening to the story, alone or together with friends, was something many students described as inspiring for the story-telling process. Some students pointed out another possibility offered, namely that it became easier to concentrate on story creation when they could relax about the formal aspects of writing. One student expressed it like this:

It is easier to concentrate on the story when you don't have to bother about the spelling and asking the teacher or a friend all the time.

As mentioned, students felt freer to use words that fit the intention they had in their writing. This freedom to choose words based on their intentions, was made possible by of the use of the word processing program and the access to spelling scaffolding.

\subsubsection{Accessibility}

In this article, accessibility refers to the possibilities students have for participation based on equal conditions in the writing activities. According to the students' descriptions, digital writing made all texts readable, regardless of which student wrote the text. That could mean that when writing digitally, it was not possible to see if someone had spelling difficulties or knew when to use punctuation, as the texts look the same. One comment related to accessibility, where students that have concentration difficulties could focus better when writing digitally: 
It's easier to sit still and focus, you can sit on the couch and have headphones on.

Also, if a student had problems due to weak motor skills, they could write as much as the other students if they wanted to, according to the students. A few students also said that writing digitally could result in less help being needed from the teacher, for example help with spelling.

\subsection{Constraints for writing stories through the use of digital tools}

In the beginning of this section, students mostly expressed the possibilities of digital writing, the loss being the opportunity to write in a personal style. The use of digital tools made all texts look the same, regardless of which student wrote the text. Another constraint described was that digital writing demanded less bodily activity, which was perceived as a negative constraint.

In summary, the empirical findings of the affordance analysis provide insights on action possibilities, as well as the constraints which digital writing tools create for students. An extended analysis in relation to the concept of student agency is presented in Table 2 . The results in relation to the concept of agency will be discussed in the next section.

\section{Discussion and conclusion}

The overall research question in this study was to investigate how access to digital writing tools and the affordances of writing tools could be understood in relation to student agency. The ways in which digital access and the affordances offered by digital tools can be understood, according to students' perceptions, will be discussed in the following section.

\subsection{Student agency in relation to digital access}

The relationship between students' access to digital tools for writing and student agency will be discussed in this section. Most of the students in this study shared

Table 2 Affordances, action possibilities and agency

\begin{tabular}{|c|c|c|}
\hline Affordance & Action possibilities & Agency \\
\hline Write-ability & $\begin{array}{l}\text { Digital writing affords possibilities } \\
\text { for writing readable texts. }\end{array}$ & $\begin{array}{l}\text { Students may have more opportunities for } \\
\text { communicating and develop language } \\
\text { through the achievement of agency. }\end{array}$ \\
\hline Edit-ability & Possibilities for editing the text. & $\begin{array}{l}\text { Achieved agency for writing more freely } \\
\text { and more independently. }\end{array}$ \\
\hline Story-telling-ability & $\begin{array}{l}\text { Possibilities for being inspired. } \\
\text { Possibilities for focusing. }\end{array}$ & $\begin{array}{l}\text { Increased possibilities for making } \\
\text { independent decisions in how to } \\
\text { imagine, create stories and focus. }\end{array}$ \\
\hline Accessibility & $\begin{array}{l}\text { Possibilities for writing precise } \\
\text { texts, and to be less dependent } \\
\text { on teachers }\end{array}$ & $\begin{array}{l}\text { Increased possibilities for participating } \\
\text { in writing activities. Increased } \\
\text { possibilities for independent judgement. }\end{array}$ \\
\hline
\end{tabular}


digital tools with their family members at home. In relation to student agency, this implies that some students have fewer opportunities to achieve agency than others. How these aspects are related is explained by Samuelsson (2014) as an inequity. The fact that digital tools at home are often shared with other family members can result in low use of digital tools for this group of students. A prerequisite for being able to use the potential of digital writing tools is the accessibility of those tools. In the present study, a small number of students did not have access to digital tools at home at all.

Access to digital tools, as well as the possibilities of practising with the digital tools, differs in Swedish students' homes with reference to socio-economic background and the parents' educational level (Medierådet, 2017). Therefore schools have an important role, as proposed by van Deursen and van Dijk (2014) and Samuelsson (2014), of bridging this inequity. In the study at hand, the most common writing tool when writing stories in the classroom, was shown to be the pen. Some students described how digital writing tools were never used in writing activities, even though the school had them. Not allowing students to use digital writing tools in education can be seen as denying the students agency. With the changes made in the Swedish curriculum regarding digitalisation, with the aim of equal digital access and digital competence for everyone in the school system, (Swedish Ministry of Education 2017a) Swedish schools should provide a writing education that enables students to develop their digital writing.

In order to create opportunities for students to achieve agency when writing, one requirement seems to be that students should have the possibility of taking advantage of the affordances offered by digital writing tools in school. One consequence of students' unequal preconditions, is that different students perceive different affordances (cf. Björkvall and Karlsson 2011). In this study, some of the students who had low levels of access to digital tools at home, expressed the need for practice. One example of this was the need to easily find the letters on the tablets, before they were given tasks involving writing stories. This is in line with Simpson and Walsh (2014) who reported that there was a lack of focus on scaffolding about the use of the technology in the educational writing context. Some affordances need to be practised. Although all students may be able to discover an affordance, all students may not be able to exploit these affordances (Danielsson and Selander 2016; Hutchby 2001). The tools available for the students, and the teaching designed by the teacher, affects the choices that can be made by students. Allowing students to make independent choices in meaning making is to allow student agency (Baynham 2006; Selander and Kress 2010). The activity of producing a text, using a word processing program, requires the user being able to both view and utilise the affordances offered by the program. Giving students these possibilities, is about enabling student agency. One adaption in the writing education environment to increase student agency, could be to give students the opportunity to choose different tools for writing, as well as giving them opportunities to practise, in order to achieve the affordances offered (Selander and Kress 2010).

\subsection{Student agency in relation to the affordances perceived}

How the relationship between students' perceived affordances and agency can be understood, is presented in this section. In relation to student agency, the affordance of writeability can mean an increased capacity to communicate because of the possibility of creating readable texts. When students in this study knew that the letters they produced 
became standardised, they could write more, and write more freely because they knew that their text would be readable for everyone. This can be understood as improved writeability, and can increase students' possibilities of being designers as well as giving them the opportunity to act more independently (cf. Selander and Kress 2010). The affordance of write-ability in relation to students' increased agency can also be understood as students being enabled to develop their language. This is because of the possibility of varying their word usage, and not just using words that they are sure about spelling correctly.

Students in this study, as in the study of Taipale (2014), expressed that the affordance of edit-ability, afforded them the possibility to edit the text easily, if the teacher told them to make changes. When editing digitally students need not be afraid of having to erase by hand, and rewrite everything. The digital writing process includes a great deal of editing while writing, instead of the linear writing process when writing by hand. When writing in a linear process by hand it is harder to make changes (Kress 2003; Stapleton 2012; Åkerfeldt 2014). Accordingly, the affordance of edit-ability can be understood as the possibility for increased agency to write more freely, and for students to become designers of their own text. Having to erase by hand was a great obstacle to many students, because it made the paper grey and messy. Students in this study perceived that they could produce more text, and that the opportunities to communicate increased when using digital tools (cf. Taipale 2014). In relation to student agency, according to the results, the affordance of story-telling-ability can imply increased opportunity for the students involved to imagine, and to create stories. The students perception of becoming inspired to create stories can be related to being designers of their own text. In turn, being designers of the text can imply more independence in text creation.

The affordance of accessibility in relation to student agency can be understood as being due to increased accessibility, students can expand their possibilities of participating in writing activities. According to the students, digital writing tools can make it easier to produce letters, which can reduce the physical difficulties of writing as well as affecting the way students compose their writing. Thereby, the possibilities for writing are changed in favour of student agency (cf. Barton 2007). If digital writing tools can be used as an extended opportunity to participate on more equal terms, regardless of the difficulties of spelling or letter formation, the learning environment can be seen to be designed to accommodate the students. This was also seen in other Swedish studies (Agélii Genlott and Grönlund 2013; Hultin and Westman 2014; Liberg 2014). Students in this study also expressed feeling freer to use words that fit the intention they had in their writing, when writing digitally. One reason for this was that they could choose words based on their intentions because of being able to use the word processing program including digital access to spelling scaffolding. The tools can be seen as means of mediating the purposes the student has (Björkvall and Karlsson 2011). When students are regarded as agents, able to make choices according to the resources available, and according to their intentions for the text, they can be regarded as independent writers, something that can also be seen as a step in the direction of educational equity. From choice, and with the resources available, teachers design their teaching, based on educational interest. Then, the student creates his or her own learning from the resources given by the teacher. How different students respond to what is offered, depends on interest and previous experience concerning the resources offered to them (Kress 2010). When students are given the resources needed in order to 
express their intentions, the meaning making process can be seen as a part of the change in communication, where knowledge can be created by everyone (Kress 2010).

The students in this study provide examples of how the affordances of digital writing can contribute to equity in writing activities. Some students stated that even if they did discover an affordance, in order to take advantage of its full potential it was necessary to have the chance to practise (cf. Danielsson and Selander 2016; Hutchby 2001). Design involves how a learner is given opportunities to make his or her own choices, based on the semiotic resources available, and in accordance with the purpose and aim of the representation (Kress 2010; Rostvall and Selander 2008). Kress (2010) states that being familiar with the affordances provided by different modes and media is crucial for making choices. In order to be able to become familiar with the affordances offered, students need to have digital access. As has been shown in this study, as well as in the studies by Samuelsson (2014) and Statens medieråd (2017), home access to digital tools differs among primary school students. Because of students' different pre-conditions, students should have the opportunity to utilise the affordances offered by digital writing in the classroom (cf Samuelsson 2014). The main conclusion in this study is that given the conditions of digital access and opportunities for practice, the affordances of digital writing can increase student agency. In turn, this suggests that a writing education focusing on student agency can contribute to equity in writing activities. Allowing student agency can mean a shift in power in education. It is important to take this shift into consideration when teachers are designing their teaching (Leijon and Lindstrand 2012).

\section{Limitations and future research}

As contemporary digital meaning making includes the use of various resources, such as images, music and speech, it would be advantageous to have a multimodal approach in future research on affordances and agency in young people's creation of stories. As this study only includes students' perceptions on making meaning while writing, this could be seen as a limitation in the study.

Open Access This article is distributed under the terms of the Creative Commons Attribution 4.0 International License (http://creativecommons.org/licenses/by/4.0/), which permits unrestricted use, distribution, and reproduction in any medium, provided you give appropriate credit to the original author(s) and the source, provide a link to the Creative Commons license, and indicate if changes were made.

Publisher's Note Springer Nature remains neutral with regard to jurisdictional claims in published maps and institutional affiliations.

\section{References}

Agélii Genlott, A., \& Grönlund, Å. (2013). Improving literacy skills through learning by writing: The iWTR method presented and tested. Computers \& Education, 67, 98-104. https://doi.org/10.1016/j. compedu.2013.03.007.

Agélii Genlott, A., \& Grönlund, Å. (2016). Closing the gaps: Improving literacy and mathematics by ictenhanced collaboration. Computers \& Education, 99, 68-80. https://doi.org/10.1016/j. compedu.2016.04.004. 
Åkerfeldt, A. (2014). Re-shaping of writing in the digital age - A study of pupils' writing with different resources. Nordic Journal of Digital Literacy, 9(3), 172-193.

Barton. (2007). Literacy: An introduction to the ecology of written language. Oxford: Blackwell Publishing.

Baynham, M. (2006). Agency and contingency in the language learning of refugees and asylum seekers. Linguistics and Education, 17, 24-39. https://doi.org/10.1016/j.linged.2006.08.008.

Bezemer, J., \& Kress, G. (2016). Multimodality, learning and communication, a social semiotic frame. Oxon and New York: Routledge.

Biesta, G. J. J., \& Tedder, M. (2006). How is agency possible? Towards an ecological understanding of agency-as-achievement (working paper 5). Exeter: The Learning Lives Project.

Björkvall, A., \& Jacquet, E. (2014). Skrivande och textskapande med datorer i högstadiet : Ett ekologiskt perspektiv på möjligheter och utmaningar med "en-till-en"-projekt. Viden om Laesning, 16, 18-27 Retrieved from http://urn.kb.se/resolve?urn=urn:nbn:se:oru:diva-55570.

Björkvall, A., \& Karlsson, A.-M. (2011). The materiality of discourses and the semiotics of materials : A social perspective on the meaning potentials of written texts and furniture. Semiotica, 187(1-4), 141-165. https://doi.org/10.1515/semi.2011.068.

Clarke, B., \& Svanaes, S. (2012). One-to-one tablets in secondary schools. An evaluation study. Stage 1: 2011- 2012. London: Family, Kids \& Youth.

Creswell, J. W. (2014). Research design: Qualitative, quantitative and mixed methods approaches (4th ed.). Thousand Oaks, CA: Sage.

Dahlström, H. \& Boström, L. (2017). Pros and Cons : Handwriting versus digital writing. Nordic Journal of Digital Literacy, 12(4), 143-161.

Danielsson, K., \& Selander, S. (2016). Se texten! Multimodala texter i ämnesdidaktiskt arbete. Stockholm: Natur och Kultur.

Emirbayer, M., \& Mische, A. (1998). What is agency? American Journal of Sociology, 103(4), 962-1023.

Erixon, P. O. (2016). Punctuated equilibrium-Digital Technology in Schools' teaching of the mother tongue (Swedish). Scandinavian Journal of Educational Research, 60(3), 337-358. https://doi.org/10.1080 /00313831.2015.1066425.

Fortunati, L., \& Vincent, J. (2014). Sociological insights on the comparison of writing/reading on paper with writing/reading digitally. Telematics and Informatics, 31(1), 39-51. https://doi.org/10.1016/j. tele.2013.02.005.

Ghandoura, W. A. (2012). A qualitative study of ESL college students' attitudes about computer-assisted writing classes. English language teaching, 5(4), 57-64. https://doi.org/10.5539/elt.v5n4p57.

Gibson, J. J. (1986). The ecological approach to visual perception. Hillsdale: Erlbaum.

Graneheim, U., \& Lundman, B. (2004). Qualitative content analysis in nursing research: Concepts, procedures and measures to achieve trustworthiness. Nurse Education Today, 24(2), 105-112. https://doi.org/10.1016 /j.nedt.2003.10.001.

Grey, D. E. (2013). Doing research in the real world (3rd ed.). London: Sage.

Håkansson Lindqvist, M. (2013). Possibilities and challenges for TEL from a student perspective through the uptake and use of digital technologies in a 1:1 initiative. Education Inquiry, 4(4), 629-647. https://doi. org/10.3402/edui.v4i4.23223.

Håkansson Lindqvist, M. (2015). Gaining and sustaining TEL in a 1:1 laptop initiative: Possibilities and challenges for teachers and students. Computers in the Schools, 32(1), 35-62. https://doi.org/10.1080 /07380569.2015.1004274.

Hultin, E., \& Westman, M. (Eds.). (2014). Att skriva sig till läsning: Erfarenheter och analyser av det digitaliserade klassrummet. Malmö: Gleerup.

Hutchby, I. (2001). Technologies, texts and affordances. Sociology, 35(2), 441-456. https://doi.org/10.1177 /S0038038501000219.

Kiss, T., \& Mizusawa, K. (2018). Revisiting the pedagogy of multiliteracies: Writing instruction in a multicultural context. Changing English, 25(1), 59-68. https://doi.org/10.1080/1358684X.2017.1403283.

Klerfelt, A. (2007). Barns multimediala berättande: En länk mellan mediakultur och pedagogisk praktik. (Doktorsavhandling). Göteborg Studies in Educational Sciences 256. Göteborg.

Kress, G. (2003). Literacy in the new media age. London: Routledge.

Kress, G. (2010). Multimodality: A social semiotic approach to contemporary communication. London: Routledge.

Kress, G. (2017). Semiotic work: Design, transformation, transduction. In E. Insulander, S. Kjällander, F. Lindstrand, A. Åkerfeldt (Eds.), Didaktik I omvandlingens tid. Text, representation, design. (pp. 39-52).

Kvale, S. (2007). Doing interviews. London: SAGE Publications AB. 
Leijon, M., \& Lindstrand, F. (2012). Socialsemiotik och design för lärande. Två multimodala teorier om lärande, representation och teckenskapande. Pedagogisk Forskning I Sverige 2012, 17(3-4), 171-192 http://journals.lub.lu.se/index.php/pfs/article/view/9412/8174.

Liberg, C. (2014). Att använda dator i tidig läs- och skrivundervisning 2011-2014, Uppsala Kommun. Report from ALS-projektet. Uppsala: Uppsala Universitet.

Mangen, A., \& Balsvik, L. (2016). Pen or keyboard in beginning writing instruction? Some perspectives from embodied cognitions. Trends in Neuroscience and Education. https://doi.org/10.1016/j.tine.2016.06.003.

Merchant, G. (2007). Writing the future in the digital age. Literacy, 41, 118-128. https://doi.org/10.1111 j.1467-9345.2007.00469.

Merriam, S. B. (1998). Qualitative research and case study applications in education. San Francisco: Jossey-Bass.

Miles, M. B., Huberman, A. M., \& Saldaña, J. (2014). Qualitative data analysis: A methods sourcebook (3rd ed.). Los Angeles: Sage.

Norman, D. A. (1990). The design of everyday things. New York: Doubleday.

Olofsson, A., Lindberg, O., \& Fransson, G. (2017). State of the art technology? Mapping students' talk about information and communication technology in upper secondary schools. The International Conference on Information Communication Technologies in Education (ICICTE 2017) Proceedings Southampton Solent University, United Kingdom.

Park, S., \& Jae Kim, G. (2014). Lessons from South Korea's digital divide index (DDI). Journal of Policy, Regulation and Strategy for Telecommunications, Information and Media, 16(3), 84-72.

Rostvall, A. \& Selander, S. (red.) (2008). Design för lärande. Stockholm: Norstedts akademiska förlag.

Samuelsson, U. (2014). Digital (o) jämlikhet? IKT-användning i skolan och elevers tekniska Kapital. (Avhandling). Högskolan för lärande och kommunikation, Högskolan i Jönköping.

Selander, S., \& Kress, G. (2010). Design för lärande - ett multimodalt perspektiv. Stockholm: Norstedts.

Simpson, A., \& Walsh, M. (2014). Pedagogic conceptualisations for touch pad technologies. Australian Journal of Language \& Literacy, 37(2), 128-138.

Stapleton, P. (2012). Shifting cognitive processes while composing in an electronic environment: A study of L2 graduate writing. Applied Linguistics Review., 3(1), 151-171. https://doi.org/10.1515/applirev-2012-0007.

Statens Medieråd. (2017). Ungar \& medier 2017: Demografi. Stockholm: Kulturdepartementet.

Swedish Ministry of Education. (2017a). Nationell digitaliseringsstrategi för skolväsendet U2017/04119/S.

Swedish Ministry of Education. (2017b). Läroplan för grundskolan, förskoleklassen och fritidshemmet 2011: Reviderad 2017. Stockholm: Skolverket.

Taipale, S. (2014). The affordances of reading/writing on paper and digitally in Finland. Telematics and Informatics, 31(4), 532-542. https://doi.org/10.1016/j.tele.2013.11.003.

van Deursen, A. J., \& van Dijk, J. A. (2014). The digital divide shifts to differences in usage. New Media \& Society, 16(3), 507-526. https://doi.org/10.1177/1461444813487959.

van Leeuwen, T. (2005). Introducing social semiotics. London: Routledge.

Vetenskapsrådet. (2017). God forskningssed. Stockholm: Vetenskapsrådet. 